\title{
Pattern of tobacco usage among the secondary school students in Qom
}

\author{
Abolfal Mohammadbeigi ${ }^{1}, *$ Mohammad Aligol $^{2}$, Narges Jafarai Afzal ${ }^{3}$
}

Sri Lanka Journal of Child Health, 2021; 50(3): 430-435

\begin{abstract}
Background: Tobacco use, including smoking, chewing or inhaling any type of tobacco product is increasing worldwide, especially in adolescents and high school students.
\end{abstract}

Objectives: To assess the pattern of tobacco use in the first and second grade high school students in Qom.

Method: A cross-sectional study was conducted among 823 first and second grade secondary education students in Qom in 2019. Global Youth Tobacco Survey (GYTS) questionnaire was used to collect data. Data were analysed using independent t-test and Chi square.

Results: Overall $43.6 \%$ of students had tobacco use experience and $22.1 \%$ were currently using tobacco. Students who had 'ever smoked' cigarettes were $42.1 \%$. Boys were more likely than girls to have 'ever smoked' cigarettes. Current tobacco smokers were $20.2 \%$ and current smokers of other tobacco, such as water pipes, were $14.9 \%$.

Conclusions: Overall prevalence of tobacco use in the high school students of Iran was high. The most commonly used tobacco among respondents was smoked tobacco other than cigarette, like water pipes. Age was found to be an independent predictor of tobacco use among students.

DOI: http://doi.org/10.4038/sljch.v50i3.9691

(Keywords: Tobacco, students, smoking, cigarette consumption)

${ }^{1}$ Department of Epidemiology, ${ }^{2}$ Department of Public Health, Faculty of Health, Qom University of Medical Sciences, Qom, Iran, ${ }^{3}$ Department of Environmental Health, Deputy of Health, Qom University of Medical Sciences, Qom, Iran

*Correspondence: aligol1389@gmail.com

iD https://orcid.org/0000-0001-8549-5791

(Received on 26 July 2020: Accepted after revision on 18 September 2020)

The authors declare that there are no conflicts of interest

Funded by the Qom Education Office and Qom University of Medical Sciences, Iran

Open Access Article published under the Creative

Commons Attribution CC-BY (CC) (P)

\section{Introduction}

Tobacco use is a preventable cause of death globally ${ }^{1}$. According to the World Health organization (WHO), a tobacco consumer is someone who uses some type of tobacco product daily or occasionally ${ }^{2}$. Tobacco smoking is an important health-related behavioural factor in current society ${ }^{3}$. Smoking is a major risk factor for cancer, chronic lung disease and cardiovascular disease $^{4}$. In addition, many non-smokers suffer from unwanted exposure to tobacco smoke ${ }^{5}$. There are about 250 million smokers in the world and an equal number of people who use chewing tobacco, most of whom are also using other carcinogens ${ }^{6}$. Tobacco smoking causes at least 7 million deaths worldwide each year, 6 million of which are directly related to tobacco, and about 890,000 people die from secondhand smoking ${ }^{7}$. Smoking is responsible for $90 \%$ lung cancers, $40 \%$ other cancers, $75 \%$ respiratory diseases, $50 \%$ cardiovascular diseases, 30\% deaths between $30-50$ years of age and $12 \%$ total deaths ${ }^{8}$. The lifestyle is predominantly established during adolescence and $70 \%$ of deaths occur as a result of behaviours that were modifiable in adolescence ${ }^{9}$. One in five smokers in the world are teenagers 13 to 15 years old, and 100,000 teenagers a day start smoking ${ }^{10}$.

The prevalence of smoking in men is globally $48 \%$ versus $10 \%$ in women and three-quarters of deaths from smoking occur in men ${ }^{6}$. The worldwide survey of tobacco use in adolescents showed that tobacco use in the age group of $13-15$, was $5.1 \%$ in boys and $4.8 \%$ in girls ${ }^{11}$. Many people start smoking from their adolescent years ${ }^{12}$. Currently, there are 4.7 million secondary school students in the world who smoke ${ }^{13}$. Although tobacco use has declined sharply over the past 40 years, one in 20 teens are still smoking $^{14}$. Tobacco-free programmes, taxes and tobacco prices, and effective prevention programmes can control tobacco use ${ }^{15}$. In particular, adolescents are affected by other factors such as smoker peers, parental smoking, access to tobacco, exposure to tobacco use and weak self-esteem or self-confidence ${ }^{16}$. Various studies have shown different rates of tobacco use among students in Iran ${ }^{17,18}$. Information on tobacco use among students is insufficient in Qom. This study was developed to help fill this data gap.

\section{Objectives}

To investigate the pattern of tobacco use in the first and second grade high school students in Qom. 


\section{Method}

A descriptive-analytical cross-sectional study was conducted among secondary grade high school students in Qom in December 2019. The study population comprised all male and female secondary grade high school students. Data were collected under the supervision of a trained data collector after coordination and agreement with the teachers. The teachers left the classroom and students were told to voluntarily fill in the questionnaires. To maintain confidentiality, the questionnaires were selfadministered and completed anonymously. Participants were informed about the voluntary nature of the study orally. The questionnaire took about 15-20 minutes to complete. Finally, 823 eighth, ninth, tenth, eleventh and twelfth graders participated in the survey. They were aged 13-18 years at the time of the survey.

The sample size was calculated using single population proportion formula. According to the results of Karimi $\mathrm{M}$, et $a l^{5}$ study, considering the smoking rate as $46 \%$ among students, $\alpha$-error 0.05 , and $95 \%$ confidence interval, the minimum sample size was calculated to be 596 students. After considering the design effect and with $10 \%$ nonresponse rate, finally 823 eligible students were selected. Multistage sampling method was used to select the eligible subjects. In the first stage, four schools were selected randomly from each of the four educational districts, including one girls' and one boys' first secondary school, and one girls' and one boys' second secondary school. Subsequently, one class of each grade in each school was selected by simple random sampling and included in the final study. Finally, 40 classes of eighth, ninth, tenth, eleventh and twelfth grades in 4 educational districts were selected. In each class, all consenting students were included in the research and finally 823 students were studied.

In this study, the Persian version of the Global Youth Tobacco Survey (GYTS) questionnaire was used to determine the prevalence and status of tobacco use among students. This questionnaire is selfadministered and collects the prevalence of tobacco use among young people, feelings toward stopping smoking, role of the media and advertising on young people's smoking, access to cigarettes, exposure to other people's smoking and knowledge of messages that are against using tobacco. All the questions were multiple choices and were translated into the
Persian language. This questionnaire was validated by Karimy $\mathrm{M}$, et $a l^{5}$ in Iran with some minor modifications to improve its validity and make it appropriate for local use. Both the data collectors and supervisors were trained for three days on the objectives and methodology of the research, and the data collection approach. Moreover, survey procedures were designed to protect the student's privacy by allowing for anonymous and voluntary participation.

Ethical issues: All subjects were informed about the study objectives and signed the informed consent form for participating in the study. The Ethical Committee of Qom University of Medical Sciences approved the study protocol by cod IR.MUQ.REC.1398.112 at 05/11/2019.

Statistical analysis: The collected data were analysed using SPSS version 20 (SPSS Inc., Chicago, IL, USA). Specific tobacco use was calculated and categorized as current use, frequent use and ever used. Using descriptive methods, the data was summarized and prevalence of tobacco use was determined. Independent t-test and Chi square were the statistical tests used. $\mathrm{p}<0.05$ was considered significant.

\section{Results}

The mean age of students was 15.2 years, 405 (49.2\%) students being male and 418 (50.8\%) students being female. Response rate was $98 \%$. The patterns of tobacco use among students aged 13-18 years in Qom in 2019 is shown in Table 1.

Overall $43.6 \%$ of all students had tobacco use experience and $22.1 \%$ had current tobacco use. Students who had 'ever smoked' cigarettes were $42.1 \%$. Boys were more likely than girls to have 'ever smoked' cigarettes. Current tobacco smokers were $20.2 \%$ and current smokers of other tobacco such as water pipes were $14.9 \%$. Prevalence of frequent cigarette smoking was $4.3 \%$, while $28.8 \%$ of students had experience of cigarette smoking. Current and 'ever use' of smokeless tobacco was $6.0 \%$ and $8.7 \%$ respectively. The results for cigarettes smoked per day among current cigarette smokers showed that the majority of smokers (30\%) used 2-5 cigarette per day and $8 \%$ smoked more than 20 cigarettes per day (Figure 1). 
Table 1: Detailed tobacco use status among students 13-18 years of age, by gender

\begin{tabular}{|c|c|c|c|}
\hline & $\begin{array}{c}\text { n (\%) } \\
(95 \% \mathrm{CI})\end{array}$ & $\begin{array}{l}\text { Boys } \\
\text { n (\%) }\end{array}$ & $\begin{array}{l}\text { Girls } \\
\text { n (\%) }\end{array}$ \\
\hline \multicolumn{4}{|l|}{ Smoked tobacco } \\
\hline $\begin{array}{l}\text { Current tobacco smokers (Smoked tobacco any time during the } \\
\text { past } 30 \text { days) }\end{array}$ & $\begin{array}{r}162(20.2) \\
(0.19-0.01)\end{array}$ & $109(27.7)$ & $53(13.0)$ \\
\hline $\begin{array}{l}\text { Current cigarette smokers (Smoked cigarettes any time during the } \\
\text { past } 30 \text { days) }\end{array}$ & $\begin{array}{l}96(11.8) \\
(0.11-0.13)\end{array}$ & $71(17.9)$ & $25(06.0)$ \\
\hline $\begin{array}{l}\text { Current smokers of other tobacco (Smoked tobacco other than } \\
\text { cigarettes any time during the past } 30 \text { days) }\end{array}$ & $\begin{array}{l}121(14.9) \\
(0.14-0.16)\end{array}$ & $79(19.7)$ & $42(10.2)$ \\
\hline $\begin{array}{l}\text { Frequent cigarette smokers (Smoked cigarettes on } 20 \text { or more } \\
\text { days of the past } 30 \text { days) }\end{array}$ & $\begin{array}{l}35(04.3) \\
(0.41-0.45)\end{array}$ & $32(08.1)$ & $03(0.7)$ \\
\hline $\begin{array}{l}\text { Ever tobacco smokers (Ever smoked any tobacco, even one or two } \\
\text { puffs) }\end{array}$ & $\begin{array}{l}344(42.1) \\
(0.40-0.44)\end{array}$ & $187(46.6)$ & $157(37.7)$ \\
\hline $\begin{array}{l}\text { Ever cigarette smokers (Ever smoked cigarettes, even one or two } \\
\text { puffs) }\end{array}$ & $\begin{array}{l}237(28.8) \\
(0.27-0.30)\end{array}$ & $127(31.4)$ & $110(26.3)$ \\
\hline $\begin{array}{l}\text { Ever smokers of other tobacco (Ever smoked tobacco other than } \\
\text { cigarettes, even one or two puffs) }\end{array}$ & $\begin{array}{l}283(34.6) \\
(0.33-0.36) \\
\end{array}$ & $164(40.8)$ & $119(28.6)$ \\
\hline \multicolumn{4}{|l|}{$\begin{array}{ll} & \text { Smokeless tobacco } \\
\end{array}$} \\
\hline $\begin{array}{l}\text { Current smokeless tobacco users (Used smokeless tobacco any } \\
\text { time during the past } 30 \text { days) }\end{array}$ & $\begin{array}{c}49(06.0) \\
(0.58-0.62)\end{array}$ & $33(08.2)$ & $16(03.9)$ \\
\hline Ever smokeless tobacco users (Ever used smokeless tobacco) & $\begin{array}{c}71(08.7) \\
(0.86-0.88)\end{array}$ & $45(11.2)$ & $26(06.3)$ \\
\hline \multicolumn{4}{|l|}{$\begin{array}{c}\text { Tobacco use } \\
\end{array}$} \\
\hline $\begin{array}{l}\text { Current tobacco users (Smoked tobacco and/or used smokeless } \\
\text { tobacco any time during the past } 30 \text { days) }\end{array}$ & $\begin{array}{r}177(22.1) \\
(0.21-0.23) \\
\end{array}$ & $121(30.7)$ & $56(13.8)$ \\
\hline $\begin{array}{l}\text { Ever tobacco users (Ever smoked tobacco and/or used smokeless } \\
\text { tobacco) }\end{array}$ & $\begin{array}{l}355(43.6) \\
(0.42-0.45)\end{array}$ & $197(49.3)$ & $158(38.1)$ \\
\hline
\end{tabular}

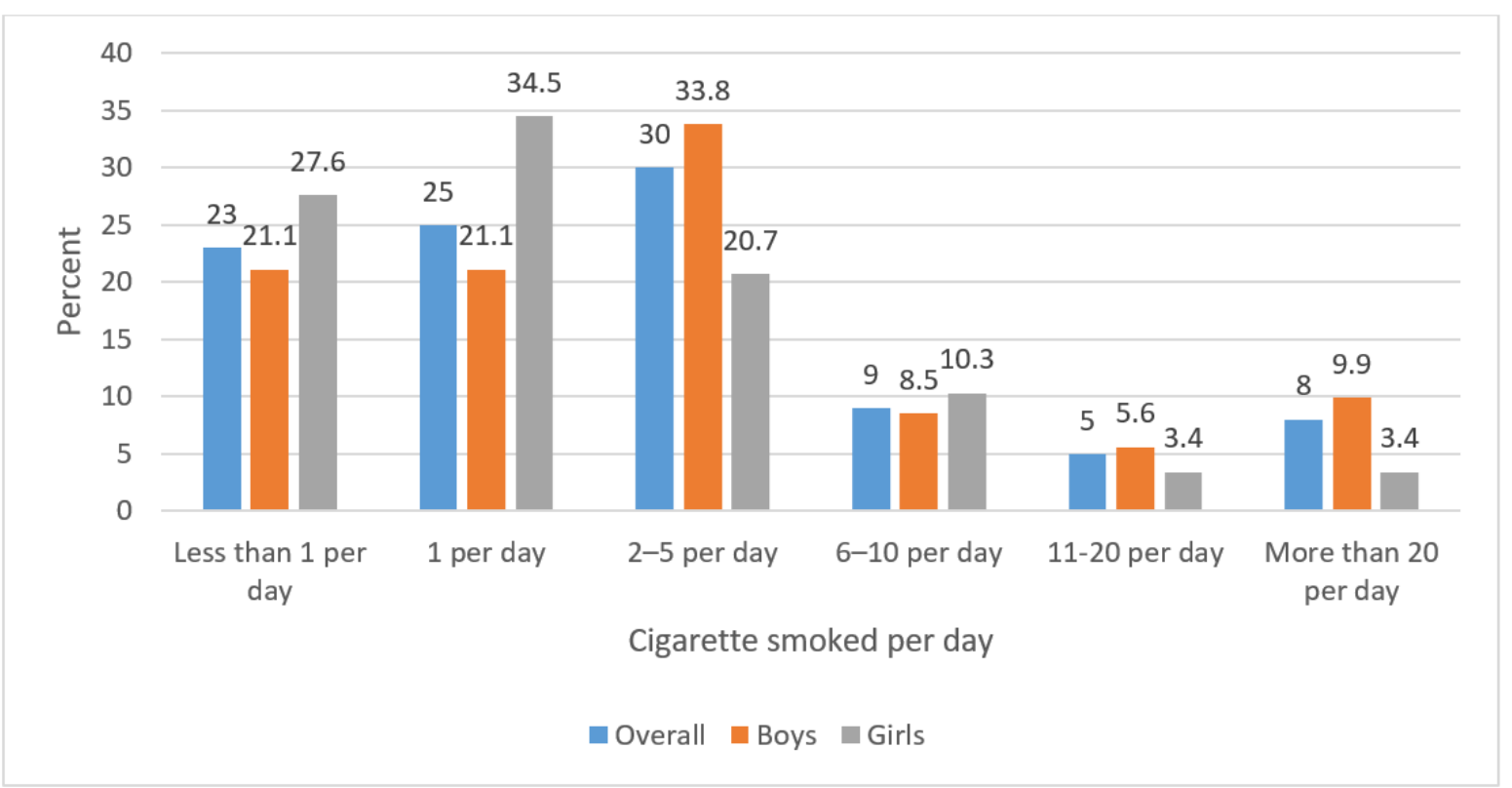

Figure 1: Cigarettes smoked per day among current cigarette smokers

There was a significant association between smoke tobacco use and age but there was no significant relationship between smokeless tobacco use and age (Table 2). 
Table 2: Relationship between age and tobacco use status

\begin{tabular}{|l|c|c|c|}
\hline \multirow{2}{*}{ Tobacco use status } & \multicolumn{2}{|c|}{ Age } & p-value \\
\cline { 2 - 3 } & Tobacco users & Non- tobacco users & \\
\hline $\begin{array}{l}\text { Current tobacco smokers (Smoked tobacco any time } \\
\text { during the past 30 days) }\end{array}$ & $15.71(1.20)$ & $15.04(1.35)$ & $<0.001$ \\
\hline $\begin{array}{l}\text { Current cigarette smokers (Smoked cigarettes any time } \\
\text { during the past 30 days) }\end{array}$ & $16.07(1.00)$ & $15.01(1.35)$ & $<0.001$ \\
\hline $\begin{array}{l}\text { Current smokers of other tobacco (Smoked tobacco } \\
\text { other than cigarettes any time during the past 30 days) }\end{array}$ & $15.77(1.25)$ & $15.08(1.34)$ & $<0.001$ \\
\hline $\begin{array}{l}\text { Frequent cigarette smokers (Smoked cigarettes on 20 } \\
\text { or more days of the past 30 days) }\end{array}$ & $16.55(0.75)$ & $15.14(1.34)$ & $<0.001$ \\
\hline $\begin{array}{l}\text { Ever tobacco smokers (Ever smoked any tobacco, even } \\
\text { one or two puffs) }\end{array}$ & $15.56(1.27)$ & $14.92(1.34)$ & $<0.001$ \\
\hline $\begin{array}{l}\text { Ever cigarette smokers (Ever smoked cigarettes, even } \\
\text { one or two puffs) }\end{array}$ & $15.70(1.25)$ & $15.00(1.34)$ & $<0.001$ \\
\hline $\begin{array}{l}\text { Ever smokers of other tobacco (Ever smoked tobacco } \\
\text { other than cigarettes, even one or two puffs) }\end{array}$ & $15.63(1.27)$ & $14.97(1.34)$ & $<0.001$ \\
\hline $\begin{array}{l}\text { Current smokeless tobacco users (Used smokeless } \\
\text { tobacco any time during the past 30 days) }\end{array}$ & $15.16(1.38)$ & $15.18(1.35)$ & $>0.05$ \\
\hline $\begin{array}{l}\text { Ever smokeless tobacco users (Ever smoked tobacco } \\
\text { and/or used smokeless tobacco) }\end{array}$ & $15.18(1.29)$ & $15.18(1.29)$ & $>0.05$ \\
\hline
\end{tabular}

p-value based on independent t-test; $p<0.05$ significant

\section{Discussion}

The overall prevalence of tobacco use in the current study was estimated to be $43.6 \%$ and the majority $(34.6 \%)$ was 'ever smokers' of other tobacco. Moreover, our results showed that the prevalence of current tobacco smoking was $20.2 \%$ and higher in boys $(27.7 \%)$ than in girls $(13.0 \%)$. These estimations in the current study were higher than estimations in other studies. Several studies have assessed the prevalence of tobacco use among students and it has ranged from $14 \%$ to $25 \%$, but a less standard survey instrument has been used ${ }^{17,18,20}$. In Madani A, et $a l^{8}$ study in Bandarabbaas, Iran, the overall prevalence of tobacco use was $23.2 \%$. The prevalence of current tobacco use was $20.2 \%$ in our study and this was more than 9 fold higher than the $2.6 \%$ in Kelishadi $\mathrm{R}$, et $a l^{21}$ study. Differences in tobacco use in various studies are due to using different assessment tools for estimation of tobacco use. Kelishadi R, et $a l^{21}$ study, used a researcher made questionnaire whereas the current study applied the GYTS. Moreover, the religious and cultural variations in different populations could be factors for different estimations.

Kelishadi $\mathrm{R}$, et $a l^{21}$ study showed that prevalence of current smoking in boys and girls was 3.5\% and $1.7 \%$, while in our study the estimates were $27 \%$ and $13 \%$, respectively. This difference might be due to study area difference in the availability and price of tobacco. The overall prevalence of current cigarette smoking in our study was $11.8 \%$ which was higher than Madani A, $a l^{8}$ study (13.7 for boys and 3.4\% for girls). The higher prevalence smoking in our population could be as a results of more accessibility of tobacco products in Qom due to higher hubble- bubble and teahouses in Qom in comparison to other cities of Iran.

In this study, prevalence of 'ever smoked' cigarettes was $42.1 \%$ which was higher than the $5.1 \%$ in the GYTS study in Bangladesh ${ }^{22}$. This difference may be as a result of availability of cigarette than other tobacco products in Iran. Prevalence of students who had smoked tobacco currently was $20.2 \%$ and $14.9 \%$ of them used other modes of smoking tobacco such as water pipes. With regard to trends in use of water pipe in the recent two decades in Iran, this result is not unexpected ${ }^{23}$.

While $28.8 \%$ of students had experience of cigarette, $4.3 \%$ of them were frequent cigarette smokers. The study conducted with Centres for Disease Control and Prevention (CDC), showed, the prevalence of current frequent cigarette use, among adolescences increased from $12.7 \%$ in 1991 to, to $7.3 \%$ in $2009^{24}$. In comparison with prevalence of frequent cigarette use in the general population, this result is low, but with regard to the importance of adolescence age, it is very considerable to monitor the trends. 'Smokeless tobacco' use, in comparison with other types of tobacco use had less prevalence, probably because it is not very common in Iran traditionally.

In this study, tobacco use significantly associated with age, which is consistent with the study done in Isfahan $^{21}$. A study done among children and adolescents showed that the older age was associated with lifetime tobacco use $\mathrm{e}^{25}$. This might be to underestimate the problem and effects of friends or social norms that may arise from socioeconomic status. The prevalence of smoking in adolescence 
causes this vulnerable age group to face numerous public health problems in the future. Boys are more likely than girls to use tobacco but advertising by the tobacco industry is making cigarettes common among girls and in the future we may have more problem with girls.

Today, tobacco use is one of the most prevalent unhealthy behaviours. Prevalence of tobacco use between different age and gender groups is different. Because of the importance of adolescence in shaping adulthood behaviours, this period of life is important for prevention of tobacco use ${ }^{19}$. This study is a means of providing baseline data for tobacco control intervention among students. The GYTS is a standardized and adaptable tools for assessing the study goals and it is relatively simple and inexpensive to apply.

\section{Conclusions}

The overall prevalence of tobacco use in the current study among high school students of Iran was high. The most commonly used tobacco among the respondents was 'smoked tobacco' other than cigarette such as water pipes. Age was found to be an independent predictor of tobacco use among students.

\section{Acknowledgements}

We forward our heartfelt gratitude to the Qom Education Office and Qom University of Medical Sciences for collaboration of this research.

\section{References}

1. Bauer UE, Briss PA, Goodman RA, Bowman BA. Prevention of chronic disease in the 21st century: elimination of the leading preventable causes of premature death and disability in the USA. Lancet 2014; 384(9937): 45-52. https://doi.org/10.1016/S01406736(14)606 48-6

2. World Health Organization. WHO policy on non-recruitment of smokers or other tobacco users. Available at: https://www.who.int/employment/FAQs_s moking_English.pdf. (Accessed January 20, 2020).

3. Wolf PA, D' Agostino RB, Kannel WB, Bonita R, Belanger AJ. Cigarette smoking as a risk factor for stroke: the Framingham Study. JAMA 1988; 259(7): 1025-9. https://doi.org/10.1001/jama.259.7.1025 PMid: 3339799

4. Warren GW, Alberg AJ, Kraft AS, Cummings KM. The 2014 Surgeon
General's report:"The Health

Consequences of Smoking-50 Years of Progress": a paradigm shift in cancer care. Cancer 2014; 120(13): 1914-6.

https://doi.org/10.1002/cncr.28695

PMid: 24687615 PMCid: PMC5928784

5. Karimy M, Niknami S, Heidarnia A, Hajizadeh I. Assessment of knowledge, health belief and patterns of cigarette smoking among adolescents. Journal of Fasa University of Medical Sciences 2011; 1(3): 142-8.

6. Edwards R. ABC of smoking cessation: the problem of tobacco smoking. British Medical Journal 2004; 328(7433): 217. https://doi.org/10.1136/bmj.328.7433.217 PMid: 14739193 PMCid: PMC318495

7. World Health Organization. Tobacco 2018. Available from: http:/who.int/topics/tobacco/en/.

8. Madani A, Aghamolaei T, Madani M, Zarei F. Prevalence of smoking and associated internal and external factors in high school students in Bandar Abbas, Iran. Journal of Preventive Medicine 2016; 2(4): 39-49.

9. Karimy M, Niknami S, Heidarnia AR, Hajizadeh I. Measuring constructs of theory of planned behaviour (TPB) regarding cigarette use among adolescents. Journal of Kermanshah University of Medical Sciences 2013; 16(8): 617-25.

10. Fong GT, Cummings KM, Borland R, Hastings G, Hyland A, Giovino GA, et al. The conceptual framework of the International Tobacco Control (ITC) policy evaluation project. Tobacco Control 2006; 15(suppl 3): iii3-iii11. https://doi.org/10.1136/tc.2005.015438 PMid: 16754944 PMCid: PMC2593053

11. World Health Organization. WHO report on the global tobacco epidemic 2017: Monitoring tobacco use and prevention policies. 2017.

12. Walker JF, Loprinzi PD. Longitudinal examination of predictors of smoking cessation in a national sample of US adolescent and young adult smokers. Nicotine and Tobacco Research 2014; 16(6): 820-7.

https://doi.org/10.1093/ntr/ntu005

PMid: 24520129 
13. Singh T. Tobacco use among middle and high school students-United States, 2011-2015. Morbidity and Mortality Weekly Report 2016; 65. https://doi.org/10.15585/mmwr.mm6514a 1

PMid: 27077789

14. Johnston LD, Miech RA, O'Malley PM, Bachman JG, Schulenberg JE, Patrick ME. Monitoring the future national survey results on drug use, 1975-2017: Overview, key findings on adolescent drug use. 2018. https://doi.org/10.3998/2027.42/148123

15. US Department of Health and Human Services. Preventing tobacco use among youth and young adults: a report of the Surgeon General. Atlanta, GA: US Department of Health and Human Services, Centres for Disease Control and Prevention, National Centre for Chronic Disease Prevention and Health Promotion, Office on Smoking and Health. 2012; 3.

16. Williams JM, Steinberg ML, Griffiths KG, Cooperman N. Smokers with behavioural health comorbidity should be designated a tobacco use disparity group. American Journal of Public Health 2013; 103(9): 1549-55. https://doi.org/10.2105/AJPH.2013.30123 2

PMid: 23865661 PMCid: PMC3776478

17. Ebadi M, et al. Smoking prevalence: Health study from Iranian population view. Payesh 2010; 30(3): 365-72.

18. Khazaee-Pool M, Pashaei T, Mansourian M, Qorbani M, Safari O, Shojaeizadeh D. School-based smoking prevention programs for middle school students in Nowshahr-Iran: A randomized controlled trial. International Journal of Pediatrics 2016; 4(11): 3859-74.

19. Daw J, Margolis R, Wright L. Emerging adulthood, emergent health lifestyles: Sociodemographic determinants of trajectories of smoking, binge drinking, obesity, and sedentary behavior. Journal of Health and Social Behavior 2017; 58(2): 181-97. https://doi.org/10.1177/002214651770242 1

PMid: 28661779 PMCid: PMC5894852
20. Nazarzadeh M, Bidel Z, Ayubi E, Bahrami A, Tezval J, Rahimi M, et al. A survey of smoking prevalence and related risk factors among Zanjan students in 2011-2012. Journal of Advances in Medical and Biomedical Research 2013; 21(84): 11124.

21. Kelishadi R, Heshmat R, Shahsanai A, Djalalinia S, Motlagh ME, Keikha M, et al. Determinants of tobacco and hookah smoking in a nationally representative sample of Iranian children and adolescents: The Caspian-IV Study. Iranian Red Crescent Medical Journal 2016; 18(8). https://doi.org/10.5812/ircmj.31099

22. Islam SMS, Mainuddin A, Bhuiyan FA, Chowdhury KN. Prevalence of tobacco use and its contributing factors among adolescents in Bangladesh: results from a population-based study. South Asian Journal of Cancer 2016; 5(4): 186. https://doi.org/10.4103/2278330X.195339 PMid: 28032084 PMCid: PMC5184754

23. Nemati S, Rafei A, Freedman ND, Fotouhi A, Asgary F, Zendehdel K. Cigarette and water-pipe use in Iran: Geographical distribution and time trends among the adult population; A pooled analysis of national STEPS surveys, 2006-2009. Archives of Iranian Medicine 2017; 20(5): 295.

24. Control CfD, Prevention. Cigarette use among high school students-United States, 1991-2009. Morbidity and Mortality Weekly Report 2010; 59(26): 797.

25. Evren C, Evren B, Bozkurt M. Tobacco use among 10th grade students in Istanbul and related variables. Asian Journal of Psychiatry 2014; 8: 69-75. https://doi.org/10.1016/j.ajp.2013.11.016 PMid: 24655632 